\author{
Denis Noble
}

\title{
Geny a przyczynowość *
}

Ukazanie powiązań między genotypem a fenotypem jest problematyczne nie tylko ze względu na ogromną złożoność interakcji między genami, białkami i funkcjami fizjologicznymi wyższych rzędów, ale również dlatego, że paradygmatom przyczynowości genetycznej w układach biologicznych towarzyszy duże zamieszanie. W tym artykule przeanalizuję niektóre związane $\mathrm{z}$ tym błędne przekonania, zaczynając od zagadnienia definicji genu. W toku rozwoju biologii uległa ona zasadniczej zmianie - pierwotnie gen rozumiano jako przyczynę cech fenotypowych, obecnie definiuje się go jako fragment DNA. Następnie przejdę do następujących zagadnień: czy „cyfrowa” natura sekwencji DNA gwarantuje im pierwszeństwo w ciągu przyczynowym w porównaniu z dziedzicznością niezwiązaną z DNA, czy koncepcja programów genetycznych jest sensowna i użyteczna oraz jaka jest rola przyczynowości na wyższych poziomach (przyczynowości odgórnej). Metafory, które dobrze spełniały swoją funkcję podczas molekularnej fazy rozwoju biologii w ostatnich dziesięcioleciach, mają ograniczone zastosowanie w wielopoziomowym świecie biologii systemowej, a nawet mogą prowadzić do nieporozumień. Wyjaśnienie wieloczynnikowej przyczynowości genetycznej związanej z funkcjami fizjologicznymi wyższych rzędów wymaga nowych paradygmatów, które zarazem

* Denis Noble, „Genes and Causation”, Philosophical Transactions of the Royal Society A 2008, vol. 366, s. 3001-3015, http://rsta.royalsocietypublishing.org/content/366/1878/3001. full.pdf (19.12.2011). Za zgodą Autora i Redakcji z języka angielskiego przełożył Adam TRYBUs. Recenzent: Grzegorz NowaK, Zakład Biochemii UMCS, Lublin. 
pozwolą zrozumieć zjawiska badane pierwotnie przez genetykę. Modelowanie funkcji biologicznych umożliwia rozwiązanie „problemu genetycznego efektu różnicowego" i odegra istotną rolę również w wyjaśnieniu przyczynowości genetycznej.

\section{Wprowadzenie: czym jest gen?}

Na pierwszy rzut oka rozwiązanie problemu rozważanego w tym artykule wydać się może proste. Geny służą przenoszeniu cech dziedzicznych, a zatem muszą być przyczyną tych cech u każdego osobnika. I tak sprawa była postrzegana na początku debaty nad genami. Samo słowo ukuł W. Johannsen, ${ }^{1}$ ale koncepcja była w użyciu już wcześniej. Opierała się na „milczącym, niemal powszechnie akceptowanym założeniu, że istnieje jedno-jednoznaczna relacja między czynnikiem genetycznym (genem) a cechą". ${ }^{2}$

Od tego czasu pojęcie genu zmieniło się zasadniczo, ${ }^{3}$ co stanowi główny powód zamieszania przy rozważaniu problemu przyczynowości genetycznej. Pierwotnie gen definiowany był jako przyczyna dziedzicznych cech fenotypowych, takich jak kolor oczu, włosów czy skóry, kształt ciała, waga, liczba nóg, ramion, skrzydeł, a także, być może, bardziej złożonych cech, takich jak inteligencja, osobowość czy seksualność.

\footnotetext{
${ }^{1}$ Por. W. Johannsen, Elemente der exakten Erblichkeitslehre, Gustav Fischer, Jena, Germany 1909.

${ }^{2}$ E. MAYr, The Growth of Biological Thought, Harvard University Press, Cambridge, Massachusetts 1982.

${ }^{3}$ Por. P. Kitcher, „Genes”, British Journal for the Philosophy of Science 1982, vol. 33, s. 337-359 (doi:10.1093/bjps/33.4.337); MAYR, The Growth of Biological Thought...; J. DuPRÉ, The Disorder of Things, Harvard University Press, Cambridge, Massachusetts 1993; A. Ріснот, Histoire de la notion de gène, Flammarion, Paris, France 1999; E.F. Keller, The Century of the Gene, Harvard University Press, Cambridge, Massachusetts 2000; E.F. Keller, „Is There an Organism in this Text?”, w: P.R. SloAn (ed.), Controlling Our Destinies: Historical, Philosophical, Ethical and Theological Perspectives on the Human Genome Project, University of Notre Dame Press, Notre Dame, Indiana 2000, s. 273-288.
} 
Molekularna definicja genu różni się od powyższej w sposób bardzo istotny. Po odkryciu faktu, że DNA koduje białka, geny zaczęto definiować jako możliwe do zlokalizowania regiony DNA z dobrze określonym początkiem i końcem. Sprawę skomplikowało nieco odkrycie czynników regulacyjnych, ale i tak to sekwencje DNA były postrzegane jako główna przyczyna cech fenotypowych, gdyż to one determinowały, jakie białka zostaną utworzone, a białka $\mathrm{z}$ kolei oddziaływały z resztą organizmu, określając fenotyp.

Jeżeli jednak nie zaakceptujemy twierdzenia, że wszystkie dziedziczne cechy fenotypowe zależą wyłącznie od sekwencji DNA (co, jak pokażę, jest po prostu nieprawdą), wówczas geny — jak je pierwotnie definiowano - nie mogą być tym samym, co fragmenty DNA. Początkowo geny uważano za konieczną przyczynę dziedzicznych zmian fenotypowych, ponieważ tak były definiowane, a problem przyczynowości genetycznej pojawia się ponownie właśnie dlatego, że współczesna definicja utożsamia geny z sekwencjami DNA.

Nie jest to związane jedynie ze skomplikowaną kwestią zależności między naturą a wpływami środowiska. Nawet gdyby udało się rozgraniczyć te dwa czynniki i określić procentowy udział jednego i drugiego (a uważam, że podejście to jest niewłaściwe w wypadku systemów oddziaływań nieliniowych, w których udział obu tych czynników branych z osobna jest równy zeru), to i tak nie wszystkie cechy „naturalne” dałoby się wyjaśnić wyłącznie DNA. Jak przekonamy się pod koniec tego artykułu, żadnej własności genetycznej (w pierwotnym, związanym z fenotypem, sensie tego słowa) nie da się, ściśle rzecz biorąc, przypisać samemu DNA.

Biologia molekularna zatem przejęła i zasadniczo zmieniła pojęcie genu. Niewątpliwie przyczyniło się to do lepszego zrozumienia mechanizmów molekularnych, co powszechnie uznaje się za jeden z największych triumfów biologii dwudziestego wieku. Jednakże bardziej filozoficzne konsekwencje tej zmiany dla badań biologicznych na poziomach wyższych niż molekularny, choć poważne, są już znacznie słabiej zrozumiane. Do nich zaliczam problem przyczynowości gene- 
tycznej. Prowadzi to także do pytania, ,ile genów znajduje się w ludzkim genomie?", oraz do próby identyfikacji „genów” w sekwencjach DNA.

\section{Gdzie znajduje się kod genetyczny?}

Oczywiście pytanie o to, które fragmenty DNA kodują białka, jest bardzo ważnym problemem biologii molekularnej i prowadzi do grupy problemów związanych z kwestią funkcji pełnionych przez pozostałe fragmenty DNA, na które dopiero zaczynamy znajdywać odpowiedzi. ${ }^{4} \mathrm{~W}$ genetyce, w pierwotnym jej rozumieniu, nie chodzi jednak wyłącznie o problem kodowania białek. Gdyby nawet okazało się, że każdy kodujący fragment DNA odpowiada tylko jednemu białku (jak ma to miejsce w wypadku bardzo prostych organizmów), to równie uzasadnione byłoby twierdzenie (uznawane niegdyś za słuszne), że kod genetyczny znajduje się w sekwencjach białek. ${ }^{5}$ Wciąż jednak pozostaje pytanie, ,jak owe sekwencje, czy to DNA czy białek, są powiązane z danymi cechami fenotypowymi?" Współczesna biologia molekularna, począwszy od prac Watsona i Cricka, odniosła oczywiście wielki sukces, wiążąc sekwencje DNA z sekwencjami aminokwasów w białkach, lecz nie udało się wyjaśnić kwestii dziedziczenia fenotypu. Problem pozostaje otwarty niezależnie od tego, czy punktem wyjścia będą sekwencje DNA czy sekwencje białek. Jego sednem jest złożoność, z jaką organizm wykorzystuje DNA i białka przy tworzeniu fenotypu. Życie to nie zupa białkowa.

W wypadku organizmów wyższych sprawę komplikuje występowanie wielu wariantów splicingowych i genetycznej ,ciemnej materii” (tylko 1-2\% ludzkiego genomu koduje białka, duża jego część koduje

\footnotetext{
${ }^{4}$ Por. H. Pearson, „Genetics: What Is a Gene?”, Nature 2006, vol. 441, s. 398-401 (doi: 10.1038/441398a).

${ }^{5}$ Por. E. Schrödinger, Czym jest życie? Fizyczne aspekty żywej komórki, przeł. Stefan Amsterdamski, Klasycy Nauki, Prószyński i S-ka, Warszawa 1998.
} 
natomiast kwasy RNA, które nie kodują białek). ${ }^{6}$ A sytuacja dodatkowo pogarsza się, gdy weźmiemy pod uwagę zjawiska epigenetyczne (znakowanie genów). ${ }^{7}$ Problem kodu genetycznego pozostaje jednak otwarty nawet w odniesieniu do organizmów wyższych. W nieco bardziej zagmatwany sposób można by wciąż argumentować, że kod znajduje się $\mathrm{w}$ białkach. Niektórzy ${ }^{8}$ sugerują nawet, że geny należy zredefiniować jako ukończone mRNA przed translacją na sekwencję polipeptydową. ${ }^{9}$ Wówczas liczba genów mogłaby wzrosnąć z 25 tys. nawet do 500 tys. Bardziej złożoną strukturę genomu (z wieloma egzonami i intronami, a także ze względu na sposób zwinięcia się DNA w chromosom) można postrzegać jako wydajną metodę przechowywania i przekazywania ,prawdziwych” przyczyn aktywności biologicznej, czyli białek. Jeśli określimy geny jako fragmenty DNA i będziemy identyfikowali je poprzez białka, które są przez nie kodowane, ominiemy wówczas istotne kwestie genetycznych uwarunkowań fenotypu. Akceptując redefinicję pojęcia „genu”, dokonaną na gruncie biologii molekularnej, ignorujemy zatem wiele ważnych pytań. Dla wielu redefinicja ta wiązała się również z przyjęciem, że DNA jest konieczną przyczyną dziedzicznych cech fenotypowych, co było uzasadnione, biorąc pod uwagę pierwotną definicję. W moim przekonaniu za wyjątkiem kwestii tworzenia białek z DNA ta koncepcja przyczynowości nie powinna być wiązana $\mathrm{z}$ nową definicją genu. Redefinicja pojęcia genu nie jest zatem tylko problemem historycznym. Stanowi wyraz

\footnotetext{
${ }^{6}$ Por. K.S. BICKel and D.R. Morris, „Silencing the Transcriptome's Dark Matter: Mechanisms for Suppressing Translation of Intergenic Transcripts", Molecular Cell 2006, vol. 22, s. 309-316 (doi:10.1016/j.molcel.2006.04.010); PEARson, „Genetics...”.

${ }^{7}$ Por. J. QIu, „Epigenetics: Unfinished Symphony”, Nature 2006, vol. 441, s. 143-145 (doi:10.1038/441143a); A. BIRD, „Perceptions of Epigenetics”, Nature 2007, vol. 447, s. 396398 (doi:10.1038/nature05913).

${ }^{8}$ Por. np. K. Scherrer and J. Jost, „Gene and Genon Concept: Coding versus Regulation”, Theory in Biosciences 2007, vol. 126, s. 65-113 (doi:10.1007/s12064-007-0012-x).

${ }^{9}$ Por. D. Noble, „Claude Bernard, the First Systems Biologist, and the Future of Physiology", Experimental Physiology 2008, vol. 93, s. 16-26 (doi:10.1113/expphysiol.2007. 038695); D. Noble, „Commentary on Scherrer and Jost (2007) Gene and Genon Concept: Coding versus Regulation”, Theory in Biosciences 2009, vol. 128, s. 153-154 (doi:10.1007/s 12064-009-0073-0).
} 
podejścia, które należy zmienić, jeśli chcemy w pełni zrozumieć naturę stojącego przed nami wyzwania.

\section{Cyfrowe a analogowe uwarunkowanie genetyczne}

Twierdzenie, że DNA jest przyczyną wszystkich cech naturalnych, jest fałszywe głównie dlatego, że samo z siebie DNA nie robi nic. Dziedziczymy przecież również komórkę jajową, a także cechy epigenetyczne przenoszone przez plemnik (oprócz jego DNA) oraz wszystkie epigenetyczne wpływy matki i otoczenia. Oczywiście to ostatnie związane jest bardziej z „wpływami środowiskowymi” niż z wpływami natury, będę jednak argumentował, że to rozróżnienie jest nieostre. Białka inicjujące transkrypcję genów w komórce jajowej i określające wzorzec ekspresji genomu pochodzą początkowo od matki. Podobne wpływy występują w całym okresie rozwoju płodu w łonie matki, co skutkuje także długo po narodzinach. ${ }^{10}$ Granica między naturą a wpływami środowiska wcale nie jest oczywista. Przejście od jednego czynnika do drugiego jest niemal niedostrzegalne. „Lamarkizm”, czyli koncepcja dziedziczenia cech nabytych, wkrada się tutaj w stopniu jak dotąd niezbadanym. ${ }^{11}$

Dziedziczenie maszynerii komórki jajowej jest istotne z dwóch powodów. Po pierwsze, to właśnie znajdująca się w komórce jajowej maszyneria służąca do odczytu genów (składająca się z około 100 białek i powiązanej z nimi architektury rybosomowej) umożliwia wykorzystanie DNA do wytworzenia innych białek. Po drugie, dziedziczony jest również pełny zestaw pozostałych części komórki: mitochondria, retikulum endoplazmatyczne, mikrotubule, błona jądrowa i inne, a także miliardy związków chemicznych zorganizowanych w specyficzny sposób w przedziałach komórkowych. Większość tych elemen-

\footnotetext{
${ }^{10}$ Por. P. Gluckman and M. Hanson, The Fetal Matrix: Evolution, Development and Disease, Cambridge University Press, Cambridge, UK. 2004.

${ }^{11}$ Por. E. JABLONKA and M. LAmB, Epigenetic Inheritance and Evolution: The Lamarckian Dimension, Oxford University Press, Oxford, UK. 1995; E. JaBlonKA and M. LamB, Evolution In Four Dimensions, MIT Press, Boston, Massachusetts 2005.
} 
tów nie jest kodowana przez sekwencje DNA, gdyż te kodują wyłącznie RNA i białka. Lipidy, absolutnie niezbędne dla całej architektury komórki, z całą pewnością nie są tak kodowane. Charakter lipidów również określa sposób zachowania się białek. Między białkami a lipidami zachodzi obustronne, skomplikowane oddziaływanie. ${ }^{12}$

Można więc spojrzeć na całą tę sytuację w następujący sposób. Możemy wyróżnić dwa elementy składowe dziedziczności molekularnej: genom, który może być postrzegany jako nośnik informacji cyfrowej, oraz maszyneria komórkowa, która, na zasadzie kontrastu, może być traktowana jako nośnik informacji analogowej. Oba te typy nazywam „dziedzicznością molekularną”, aby podkreślić, że na tym etapie nie chodzi mi jeszcze o różnicę między genetyczną dziedzicznością molekularną a przyczynami wyższych rzędów. Maszyneria komórki jajowej ma bowiem, tak samo jak DNA, charakter molekularny. Do analizy przyczynowości wyższych rzędów przejdę nieco później.

Oba elementy składowe dziedziczności umożliwiają organizmowi przechwycenie oraz zbudowanie nowych molekuł warunkujących jego rozwój, ale w wypadku DNA i białek w grę wchodzi proces kodowania, którego brakuje w przypadku pozostałych elementów dziedziczności molekularnej. I to stanowi podstawowa różnicę.

To ze względu na etap kodowania, wiążący DNA i białka, informację wykorzystaną $\mathrm{w}$ tym procesie można postrzegać jako cyfrową. Dzięki temu możemy precyzyjne określić liczbę par zasad (3 miliardy w wypadku genomu ludzkiego). Co więcej, kod CGAT można z łatwością przetłumaczyć na kod binarny, stosowany we współczesnych komputerach. (Warto nadmienić, że w kontekście biologicznym słowo „kod” ma znaczenie metaforyczne - nikt nie wykazał, że to, o czym mówimy, można naprawdę określić tym mianem. $Z$ tego powodu niektórzy sugerują, że odpowiedniejsze byłoby słowo „szyfr”.)

\footnotetext{
${ }^{12}$ Por. A. Roux, D. Cuvelier, P. Bassereau, and B. Goud, „Intracellular Transport: From Physics to Biology", Annals of the New York Academy of Sciences 2008, vol. 1123, s. 119125 (doi:10.1196/annals.1420.014).
} 
Analogiczne, ścisłe wyliczenie informacji zawartej w drugim elemencie składowym dziedziczności molekularnej jest zaś niemożliwe. Wielość cząstek wchodzących w grę (biliony) byłaby w zasadzie bez znaczenia, gdyż wiele jest dokładnie takich samych, aczkolwiek ich organizacja i podział na sekcje też muszą być odzwierciedlone. Można zadać pytanie, jaka ilość informacji cyfrowej jest konieczna, by „odzwierciedlić" dziedziczność o charakterze pozagenomowym, ale podobnie jak w wypadku kodowania obrazów, zależy to od dokładności, $\mathrm{z}$ jaką chcemy odzwierciedlić tę informację cyfrowo. Nie ma zatem prostego rozwiązania problemu ilościowego porównania dziedziczności pochodzącej z DNA i tej spoza DNA. Jednakże, biorąc pod uwagę złożoność samej komórki jajowej — wykształcenie komórki eukariotycznej w wyniku ewolucji zajęło co najmniej 1 lub 2 miliardy lat możemy stwierdzić, że określanie genomu jako „ogromnej” bazy danych, zaś reszty komórki jako w pewnym sensie „małej” w stosunku do niej, nie może być poprawne. Gdy przyjrzymy się temu bardziej szczegółowo, to może się okazać, że komórka jajowa zawiera nawet więcej informacji niż genom. Gdybyśmy musieli „zapisać” całość cyfrowo zakodowanej informacji koniecznej do odtworzenia ziemskiego życia w jakimś odległym układzie pozasłonecznym i chcieli wysłać ją w kapsule, to jestem przekonany, że większość tej informacji miałaby charakter pozagenomowy. Wysłanie w takiej kapsule wyłącznie informacji genomowej byłoby właściwie bezcelowe. Szanse, że ktokolwiek we Wszechświecie byłby w posiadaniu komórek jajowych i macicy, pozwalających na „ożywienie” organizmów ziemskich na podstawie ich DNA, są bliskie zeru. Równie dobrze moglibyśmy wysłać w kapsule kody kreskowe produktów z najbliższego supermarketu!

\section{Czy informacja cyfrowa jest ważniejsza?}

Ilość informacji nie jest oczywiście jedynym kryterium, jakie możemy rozważyć. Niezależnie od proporcji informacji o ziemskich organizmach w naszej kapsule, pewne informacje mogą być ważniejsze od innych. A zatem, który rodzaj informacji jest ważniejszy w proce- 
sie dziedziczenia? Informacja pochodząca z komórki czy z DNA? Zapytajmy za E. Wernerem: „Jak bardzo istotny jest genom?” ${ }^{13}$ Obecny stan wiedzy naukowej dopuszcza kilka możliwości uzasadnienia tezy o większym znaczeniu DNA.

Po pierwsze, w związku z tym, że DNA można postrzegać jako informację o charakterze cyfrowym, daje to w naszym komputerowo zorientowanym świecie poczucie większej pewności i niezawodności analogicznie muzykę nagraną na płycie kompaktowej określamy jako „czystszą" i zawierającą mniej „szumów” w porównaniu z muzyką z płyty winylowej. Informacja cyfrowa ma charakter dyskretny i jest dobrze określona, podczas gdy informacja analogowa jest rozmyta i niedokładna. Nie wydaje się to jednak całkiem poprawne ujęcie. Duże genomy wymagają bowiem narzędzi naprawczych, zapewniających odpowiedni poziom precyzji. Brane jednak razem $\mathrm{z}$ tymi narzędziami stanowią solidny materiał dziedziczny. Można natomiast argumentować, że próby redukcji informacji analogowej, takiej jak dane jakiegoś obrazu, do postaci cyfrowej nigdy nie są w pełni udane, gdyż konieczny jest tu kompromis $\mathrm{w}$ takich kwestiach jak rozdzielczość. Ale takie podejście z góry zakłada wyższość DNA. Tymczasem podstawowe pytanie brzmi: „dlaczego informacja cyfrowa ma być traktowana w wyróżniony sposób?" Przecież kwas DNA wymaga kodu cyfrowego właśnie dlatego, że nie koduje wyłącznie samego siebie. Koduje molekuły innego typu, mianowicie białka. Pozostała maszyneria komórkowa nie potrzebuje kodu, ani nie musi być redukowana do postaci informacji cyfrowej i to właśnie dlatego, że ta maszyneria reprezentuje siebie sama. Do słynnego, zaproponowanego przez R. Dawkinsa, ${ }^{14}$ opisu DNA, jako odwiecznego replikatora, trzeba dodać, że komórki jajowe i plemniki również tworzą odwieczną linię, tak samo zresztą jak wszystkie organizmy jednokomórkowe. A samo DNA odwiecznej linii stworzyć nie może.

\footnotetext{
${ }^{13}$ Por. E. Werner, „How Central Is the Genome?”, Science 2007, vol. 317, s. 753-754 (doi:10.1126/science.1141807).

${ }^{14}$ Por. R. Dawkins, Samolubny gen, przeł. Marek Skoneczny, Na Ścieżkach Nauki, Prószyński i S-ka, Warszawa 1996, rozdz. 2.
} 
Tak więc możemy określić informację zawartą w komórce jako analogową tylko na zasadzie kontrastu do pojęcia informacji cyfrowej. Pamiętać jednak należy, że nie mamy tu do czynienia z analogową reprezentacja czegokolwiek. Sama w sobie komórka stanowi samowystarczalną całość, którą dziedziczymy i która powielana jest bezpośrednio. Komórki tworzą komórki, które z kolei tworzą inne komórki (używając przy tym DNA) i tak dalej. To dziedziczenie ma dość solidny charakter: komórki wątroby tworzą inne komórki wątroby przez wiele pokoleń, na każdym etapie znakując genom, by ten proces mógł być kontynuowany. W taki sam sposób zachowuje się około 200 pozostałych typów komórek w ciele. ${ }^{15}$ Należy jednak zauważyć, że genom jest taki sam dla całego organizmu. Ten wspólny kod „cyfrowy” jest tak stworzony, by reagować na zupełnie różne instrukcje pochodzące z poszczególnych typów komórek. Te instrukcje mają charakter „analogowy” i przejawiają się w ciągłej zmianie narzuconych wzorców ekspresji genów. Błędne postrzeganie ekspresji genów jako mającej charakter cyfrowy wiąże się z tendencją do skupiania się wyłącznie na kodach CGAT, a nie na stale zmiennym stopniu ekspresji. Skupianie się wyłącznie na jednym lub drugim aspekcie z pewnością nie jest odpowiednie. Jeśli idzie o wzorce różnych poziomów ekspresji, informacja ma charakter analogowy.

Wydaje się zatem, że problemu, który z rodzajów przyczynowości (genomowej czy pozagenomowej) jest ważniejszy, nie da się rozwiązać, wprowadzając rozróżnienie na informację cyfrową i analogową. Kodowanie cyfrowe można nawet postrzegać jako dość ryzykowny etap, gdyż w wypadku dużych genomów wymagana jest skomplikowana maszyneria do naprawy błędów. ${ }^{16}$ Posiadanie błon lipidowych automatycznie ,akceptujących” określone lipidy włączane w strukturę 7.

${ }^{15}$ Por. D. Noble, The Music of Life, Oxford University Press, Oxford, UK. 2006, rozdz.

${ }^{16}$ Por. J. Maynard Smith i E. Szathmáry, Tajemnice przelomów w ewolucji. Od narodzin do powstania mowy ludzkiej, przeł. Michał Madaliński, Wydawnictwo Naukowe PWN, Warszawa 2000; J. Maynard Smith, Evolutionary Genetics, Oxford University Press, New York 1998. 
komórek i pozwalające na ich rozrost, umożliwiając między innymi podział komórkowy, wydaje się rozwiązaniem w miarę niezawodnym $\mathrm{z}$ chemicznego punktu widzenia. Błony lipidowe są również dobrymi replikatorami chemicznymi. Ten proces został zapewne „odkryty” i „udoskonalony” przez ewolucję dużo wcześniej, zanim komórki „przechwyciły” geny, co rozpoczęło proces przemiany komórek do postaci dzisiejszej. Wydaje się, że komórki prymitywne, stanowiące zapewne niewiele więcej niż powłokę lipidową zawierającą kilka enzymów RNA, ${ }^{17}$ „,wiedziały”, jak dokonać podziału i rozmnożyć się, na długo przed tym, zanim w ich skład zaczęły wchodzić genomy.

\section{Niemożliwy eksperyment}

Zastanówmy się teraz, czy na drodze pewnego bezpośredniego (lecz dziś, i prawdopodobnie zawsze, niemożliwego) ${ }^{18}$ eksperymentu biologicznego można odpowiedzieć na pytanie, czy któryś z wymienionych rodzajów informacji jest ważniejszy. Rozważmy następujący problem: czy kompletna sekwencja DNA wystarczy, by „ożywić” wymarły gatunek? Na przykład, czy DNA dinozaura (pomijając wszelkie problemy techniczne) można by umieścić w, powiedzmy, komórce jajowej ptaka? Czy wówczas powstałby dinozaur, ptak czy też jakaś niezwykła hybryda?

Z pozoru taki eksperyment rozwiązałby nasz problem. Gdyby w jego wyniku urodził się dinozaur, wówczas okazałoby się, że to informacja zawarta w DNA jest ważniejsza. Informacja pochodząca spoza DNA byłaby czymś wtórnym. Wydaje się, że takiego właśnie wyniku oczekiwaliby zwolennicy „determinizmu genetycznego”. Gdyby natomiast urodził się ptak, wówczas mielibyśmy do czynienia z sytuacją odwrotną (choć panuje zgoda, że jest to bardzo mało prawdopodobny rezultat). Gdyby zaś powstała hybryda lub w ogóle nic (co wy-

\footnotetext{
${ }^{17}$ Por. Maynard Smith i Szathmáry, Tajemnice przełomów w ewolucji...; J. Maynard Smith and E. Szathmáry, The Origins of Life, Oxford University Press, New York 1999.

${ }^{18}$ Por. Keller, The Century of the Gene...; Keller, „Is There an Organism in this Text...".
} 
daje się najbardziej prawdopodobne), to i tak można by utrzymać pogląd o pierwszeństwie DNA, twierdząc, że z punktu widzenia DNA mamy do czynienia $\mathrm{z}$ błędem $\mathrm{w}$ funkcjonowaniu maszynerii komórki jajowej. Należy jednak zwrócić uwagę na wyrażenie „,z punktu widzenia DNA". DNA jest tu wyraźnie traktowane w uprzywilejowany sposób, co oczywiście przesądza sprawę.

Niektóre problemy związane z tym eksperymentem mają dość istotne znaczenie. Na przykład klonowanie międzygatunkowe ma znaczenie praktyczne jako możliwe źródło komórek macierzystych. Może to również pozwolić rozwiązać bardzo stary problem stopnia, w jakim komórki jajowe są związane $\mathrm{z}$ konkretnymi gatunkami. Wiele wczesnych teorii tak zwanego „dziedziczenia cytoplazmatycznego” zostało już odrzuconych, ${ }^{19}$ chociaż, jak zauważył E. Mayr, „Dawny pogląd o ważnej roli cytoplazmy $\mathrm{w}$ procesie dziedziczenia $[\ldots]$ jest wciąż w obiegu, uległ jednak znacznej modyfikacji”. Fakt, że większość klonów międzygatunkowych nie dożywa wieku dorosłego, wskazuje wyraźnie, że „złożona architektura cytoplazmy gra znacznie istotniejszą rolę niż sądzi się obecnie". ${ }^{20} \mathrm{~W}$ związku z tym, że w wypadku dziedziczności pozagenomowej nie istnieje odpowiednik mutacji, jedyną drogą do rozwiązania tego problemu może być posłużenie się różnymi gatunkami.

Znane są próby klonowania międzygatunkowego, nie obejmowały one jednak gatunków wymarłych. Przed około dziesięciu laty J.B. Cibelli z Michigan State University eksperymentował z umieszczeniem swojego DNA w krowiej komórce jajowej, co zaowocowało nawet opatentowaniem zastosowanej przez niego techniki. Sam eksperyment natomiast - zresztą dość problematyczny z etycznego punktu widzenia — nie powiódł się. Również późniejsze eksperymenty Cibelliego, w których próbował umieścić małpie geny w komórce jajowej krowy, zakończyły się fiaskiem. Jedynym udanym eksperymentem tego typu jest sklonowanie dzikiego wołu (bantenga Bos javanicus) przy użyciu

\footnotetext{
${ }^{19}$ Por. MAYr, The Growth of Biological Thought....

${ }^{20}$ MAYr, The Growth of Biological Thought....
} 
komórek jajowych krowy domowej. Wydaje się zatem, że technika ta działa wyłącznie w przypadku gatunków blisko spokrewnionych. $\mathrm{Z}$ wyglądu banteng bardzo bowiem przypomina krowę, a niektóre okazy zostały nawet udomowione w podobny sposób. Dużo częściej jednak klony międzygatunkowe giną już we wczesnym stadium embrionalnym.

Eksperymenty te są niewątpliwie interesujące, nie umożliwiają jednak pełnej odpowiedzi na postawione przeze mnie pytanie. Genomy i komórki wyewoluowały wspólnie ${ }^{21}$ i żadne nie może funkcjonować bez drugiego. Gdyby zatem w wyniku naszego hipotetycznego eksperymentu urodził się dinozaur, musielibyśmy uznać, że komórki jajowe dinozaurów i ptaków są wystarczająco podobne, by było to możliwe. Różnicy (między ptakami a dinozaurami) należałoby wówczas szukać w DNA, a nie w pozostałej części komórki jajowej. Pamiętajmy, że ewolucja komórki eukariotycznej miała miejsce na długo przed pojawieniem się dinozaurów i ptaków, więc większość maszynerii używanej przez te komórki musi być wspólna. Ale to nie daje podstaw do przyznania większego znaczenia jednemu $\mathrm{z}$ tych rodzajów informacji. Jeśli odtworzymy taśmę wideo nagraną w systemie PAL na czytniku kompatybilnym z tym systemem, uzyskamy efekt wyraźnie powiązany z informacją zapisaną na tej taśmie (i to również na innym czytniku PAL). Nie uzyskamy jednak żadnego efektu, używając czytnika niekompatybilnego z tym systemem. To dzięki komórce jajowej otrzymamy w rezultacie naszego eksperymentu, jeśli w ogóle, jakiś organizm posiadający wiele cech wspólnych dinozaurom i ptakom. Warto dodać, że w przypadku komórki jajowej dziedziczenie nie wpływa wyłącznie na dostrzegane różnice, lecz na wszystko, co obserwujemy. Każda funkcja wyższego rzędu zależy od czynników związanych zarówno z DNA, jak i z resztą komórki. „Analiza systemu biologicznego to znacznie więcej niż tylko rozbieranie go na części i badanie informacji cyfrowej zawartej w każdej komórce". ${ }^{22}$

\footnotetext{
${ }^{21}$ Por. Maynard Smith i Szathmáry, Tajemnice przelomów w ewolucji....

${ }^{22}$ Y. Neuman, „The Rest Is Silence”, Perspectives in Biology and Medicine 2007, vol. 50,
} 


\section{6. „Problem genetycznego efektu różnicowego”}

Jest to wersja bardziej ogólnego problemu związanego z genami (definiowanymi jako sekwencje DNA) i ich efektami. Przyporządkowanie funkcji genom zależne jest od zaobserwowanych różnic w fenotypie, będących następstwem zmian (na przykład mutacji, delecji) w genotypie. Dawkins przedstawił to w bardzo wyrazisty sposób, pisząc: ,jest bowiem podstawową prawdą, choć nie w pełni uświadomioną, że kiedy genetyk bada gen jakiejś cechy fenotypowej, zawsze odwołuje się do różnicy między dwoma allelami”. ${ }^{23}$

Jednakże same różnice nie zdają sprawy z każdej funkcji, z jaką związany może być gen, gdyż nie da się w ten sposób określić wszystkich efektów wspólnych dzikim i zmutowanym typom danego genu. Być może widzimy tylko czubek góry lodowej. Nie da się również wykluczyć, że widzimy nie ten czubek, co trzeba, ponieważ może się zdarzyć, że identyfikujemy gen poprzez patologiczne efekty tylko jednej z możliwych mutacji, nie zaś poprzez funkcję, która stanowiła przedmiot selekcji naturalnej. Przykładem może być tu większość tak zwanych onkogenów. Jest mało prawdopodobne, by selekcja naturalna faworyzowała geny, których funkcją jest powodowanie raka. Z tego właśnie względu Gene Ontology (GO) Consortium ${ }^{24}$ nie obejmuje pojęcia onkogenezy: „onkogeneza nie jest akceptowalnym terminem $\mathrm{GO}$, gdyż powodowanie zmian rakotwórczych nie jest normalną funkcją jakiegokolwiek genu". Dokładniej rzecz ujmując, powodowanie zmian rakotwórczych mogłoby być taką funkcją, gdyby ów gen miał też inne, przeważająco pozytywne efekty. Można to określić jako paradygmat „anemii sierpowatej” ${ }^{25}$ i to z tego powodu uważam, że w zasadzie onkogenetyczne działanie genu można potraktować jako

s. 625-628 (doi:10.1353/pbm.2007.0053).

${ }^{23}$ R. DAwkins, Fenotyp rozszerzony. Dalekosiężny gen, przeł. Joanna Gliwicz, Prószyński i S-ka, Warszawa 2003, s. 125-126.

${ }^{24}$ Por. http://geneontology.org/.

${ }^{25}$ Por. S. Jones, The Language of the Genes, HarperCollins, London, UK. 1993, s. 219. 
jego funkcję: balansowanie między pozytywnymi a negatywnymi skutkami genów występuje w przyrodzie bardzo często. ${ }^{26}$

Identyfikowanie genów na podstawie różnic w fenotypie powiązanych $\mathrm{z}$ tymi $\mathrm{w}$ genotypie jest zatem ryzykowne. Ponadto wiele, a zapewne większość, zmian genetycznych jest buforowanych, co sprawia, że organizmy są odporne i muszą takie być, by odnieść ewolucyjny sukces. Nawet gdy dany gen pełni jakąś ważną funkcję, może się zdarzyć, że jego delecja lub mutacja tego nie uwidocznią. Nazywam to problemem genetycznego efektu różnicowego. Twierdzę, że stanowi on poważne ograniczenie przy określaniu skutków powodowanych przez geny. Propozycja rozwiązania tego problemu zostanie przedstawiona w dalszej części artykułu.

Trzeba również pamiętać, że w wypadku każdej funkcji wyższego rzędu mamy do czynienia $z$ wieloma genami (z setkami, może więcej) i że — na tym poziomie — pojedyncze geny często są związane $\mathrm{z}$ wieloma funkcjami. Nie powinniśmy zakładać, że pierwsza dostrzeżona zależność między fenotypem a genotypem w przypadku danego genu określa jego jedyną czy też główną funkcję.

\section{Klopoty $z$ centralnym dogmatem biologii}

Odtwarzacz wideo stanowi dobry przykład na to, że maszyneria odczytująca musi być kompatybilna z zakodowanymi danymi. Jednakże w tym kontekście analogia ta ma też poważne ograniczenia. Najlepiej sprawdza się ona, gdy przyjmiemy optykę zwolenników centralnego dogmatu biologii: informacja jest przekazywana $\mathrm{z}$ zakodowanych danych do reszty systemu, lecz nie w drugą stronę. Aktualna wiedza z zakresu epigenetyki zmusza do zmiany tego poglądu. Maszyneria komórkowa nie tylko odczytuje genom, lecz również narzuca wzorce jego znakowania i ekspresji. ${ }^{27}$ Właśnie to sprawia, że określenie konkretnego wyniku naszego hipotetycznego eksperymentu jest ta-

\footnotetext{
${ }^{26}$ Por. „Faustian Pacts with the Devil”; Noble, The Music of Life..., s. 109.

${ }^{27}$ Por. Qiu, „Epigenetics...”.
} 
kie trudne. Zgodnie z centralnym dogmatem biologii, jeśli tylko użyjemy kompatybilnej komórki jajowej, wówczas na pewno otrzymamy dinozaura, gdyż to DNA rządzi całym procesem. Ale jeśli znakowanie epigenetyczne również jest ważnym czynnikiem, to i komórka jajowa gra istotną, a nie tylko pasywną rolę. Jej wpływ jest dwojaki. Po pierwsze, każdy organizm musi zostać jakoś wytworzony, a zatem komórka jajowa stanowi podstawową „przyczynę genetyczną” w tym sensie, że jest niezbędna przy tworzeniu fenotypu i jest przekazywana z pokolenia na pokolenie. Po drugie, komórka jajowa określa w pewnym stopniu rodzaj powstałego organizmu. Na pytanie, jak duży jest to udział, można niewątpliwie odpowiedzieć na drodze empirycznej, aczkolwiek znacznie utrudnia to fakt, że niemal wszystkie klony międzygatunkowe nie dożywają dorosłości. Jednakże, jak już zaznaczono, świadczy to tylko, jak ważną rolę odgrywa tu komórka jajowa.

Interesujący — i empirycznie rozstrzygalny — problem stanowi również kwestia zakresu gatunków z wystarczająco podobną maszynerią komórki jajowej, umożliwiającą funkcjonowanie różnych genomów. To jednak świadczy raczej o podobnym dopasowaniu różnych genomów do komórek jajowych różnych gatunków i ich wzajemnej kompatybilności pod względem możliwości rozwoju, nie zaś o pierwszeństwie DNA w stosunku do czynników pozagenomowych (bądź też odwrotnie). Tak czy inaczej, maszyneria komórki jajowej jest równie niezbędna, co DNA. Należy ponadto pamiętać, że „informacja” zawarta $\mathrm{w}$ tej maszynerii ma ogromne rozmiary.

Podkreślmy też, że nie tylko DNA jest przekazywane w ramach eksperymentów z klonowaniem międzygatunkowym. Za każdym razem wprowadzane jest również jądro komórkowe z całą jego maszynerią. ${ }^{28}$ Stanowi to oczywiście spore ograniczenie przy próbie oceny roli komórki jajowej. Jądro charakteryzuje się skomplikowaną budową i, poza DNA, zawiera czynniki transkrypcyjne oraz inne molekuły ma-

\footnotetext{
${ }^{28}$ Por. X.C. Tian, C. Kubota, B. Enright, and X. YAng, „Cloning Animals by Somatic Cell Nuclear Transfer - Biological Factors”, Reproductive Biology and Endocrinology 2003, vol. 1, s. 98-105 (doi:10.1186/1477-7827-1-98).
} 
jące wpływ na znakowanie epigenetyczne. Ściśle rzecz biorąc, powinniśmy rozważać skutki umieszczenia samego DNA w jądrze komórki jajowej pozbawionym genomu, nie zaś umieszczenia całego jądra (czy też tylko chromosomów) w komórce jajowej pozbawionej jądra, ale nikomu się to jeszcze nie udało. Powstaje również pytanie, czy należy wziąć pod uwagę histony, które pośredniczą w powstawaniu wielu efektów epigenetycznych? Jest to tylko jeden z powodów, dla których sklonowanie dinozaura może okazać się niemożliwe.

Podsumowując, jeśli przez przyczynowość genetyczną mamy na myśli wszystkie dziedziczne przyczyny fenotypu, to wykluczenie dziedziczenia o charakterze pozagenomowym jest po prostu błędem. Zapewne nie ma też zbytniego sensu pytanie, który rodzaj dziedziczności jest ważniejszy, gdyż wyłącznie współdziałanie czynników dziedziczności genomowej i pozagenomowej prowadzi do wytworzenia czegokolwiek. Dopiero gdy skupimy się na zmianach w fenotypie, które możemy przypisać różnicom w genotypie (a tak obecnie określa się funkcjonalność genów), możemy przekonująco argumentować, że wszystko sprowadza się do DNA, ale nawet taki wniosek nie jest do końca uzasadniony. Należałoby najpierw przeprowadzić eksperymenty określające stopień swoistości gatunkowej komórek jajowych, ponieważ znakowanie jądrowego DNA może być tu równie istotne.

\section{Programy genetyczne?}

Kolejna analogia między systemami biologicznymi a komputerami związana jest z postrzeganiem kodu DNA jako pewnego rodzaju programu. Ta koncepcja została wprowadzona przez J. Monoda i F. Jacoba $^{29}$ i dziś mamy do czynienia z całym wachlarzem odnoszących się do niej metafor. Mówimy o sieciach genów, genach nadrzędnych i przełącznikach genów. Te metafory z kolei pomogły podbudować koncepcję determinizmu genetycznego (DNA).

\footnotetext{
${ }^{29}$ Por. J. Monod and F. JACOB, „Teleonomic Mechanisms in Cellular Metabolism, Growth and Differentiation”, Cold Spring Harbor Symposia on Quantitative Biology 1961, vol. 26, s. $389-401$.
} 
Ale przecież nie ma sieci składających się wyłącznie z genów! Nawet najprostsza sieć — związana z rytmem okołodobowym — nie jest siecią genów. Nie istnieje też gen rytmu okołodobowego. A raczej, jeżeli istnieje, to istnieją także białka, lipidy i inne części maszynerii komórkowej związane $\mathrm{z}$ tym rytmem.

Sieć rytmu okołodobowego obejmuje, oprócz kodu DNA, co najmniej trzy inne rodzaje struktur molekularnych. Fragment DNA zwany genem period (per) koduje białko (PER), które jest tworzone przez maszynerię rybosomową i składowane w cytoplazmie komórkowej. Następnie białko PER przechodzi powoli przez (białkowo-lipidową) błonę jądrową i działa jako inhibitor ekspresji genu per. ${ }^{30}$ To sprawia, że ilość PER w cytoplazmie spada i w efekcie działanie inhibicyjne słabnie. W odpowiednich warunkach cały ten proces zajmuje około doby. Co ważne, to cała sieć pracuje w tym rytmie, a nie tylko sam gen. ${ }^{31}$ Niezależnie od sposobu opisu tego procesu, jest oczywiste, że nie mamy do czynienia z siecią genów. Jeżeli już chcielibyśmy tę sieć jakoś scharakteryzować, to należałoby ją określić jako sieć genowobiałkowo-lipidowo-komórkową. Badanie działania tego genu bez brania pod uwagę reszty maszynerii komórkowej nie ma zbytniego sensu. Jeśli więc ta sieć jest częścią jakiegoś „,programu genetycznego”, nie może on być programem DNA, gdyż nie jest związany wyłącznie z kodem DNA. Ponadto, na co zwrócili uwagę R. Foster i L. Kreitzman, istnieje wiele poziomów interakcji nałożonych na ów podstawowy mechanizm - do tego stopnia, że możemy dokonać delecji genu CLOCK w myszach, nie powodując przy tym utraty rytmu okołodobowego. ${ }^{32}$ Wydaje się zatem, że słuszniej byłoby traktować DNA jako

\footnotetext{
${ }^{30}$ Por. P.E. Hardin, J.C. Hall, and M. Rosbash, „Feedback of the Drosophila Period Gene Product on Circadian Cycling of Its Messenger RNA Levels", Nature 1990, vol. 343, s. 536540 (doi:10.1038/343536a0).

${ }^{31}$ Por. R. Foster and L. Kreitzman, Rhythms of Life, Profile Books, London, UK. 2004.

${ }^{32}$ Por. J.P. Debruyne, E. Noton, C.M. Lambert, E.S. Maywood, D.R. Weaver, and S.M. Reppert, „A Clock Shock: Mouse CLOCK Is Not Required for Circadian Oscillator Function", Neuron 2006, vol. 50, s. 465-477 (doi:10.1016/j.neuron.2006.03.041).
} 
bazę danych, nie zaś jako program komputerowy. ${ }^{33} \mathrm{~W}$ tym ujęciu program korzysta $z$ takiej bazy danych, lecz nie jest przez nią kontrolowany.

Genetyk roślin E. Coen ${ }^{34}$ idzie nawet dalej. Opiszę jego argumentację na swój sposób, jednakże chciałbym zaznaczyć, że jego teorie i eksperymenty miały istotny wpływ na kształtowanie się mojego podejścia do tego typu problemów. U zarania informatyki, w czasie, gdy Monod i Jacob ${ }^{35}$ rozwijali swój pomysł le programme génétique, program komputerowy określany był jako zbiór instrukcji niezależny od funkcji, jaką ma pełnić. Taki program był zamkniętym systemem logicznym, zbiorem instrukcji, zwykle przechowywanym na kartach czy taśmach, wymagającym danych do przetworzenia, by wygenerować dane wyjściowe. Stosując to podejście do kwestii relacji DNA i czynników o charakterze pozagenomowym, otrzymujemy koncepcję, wedle której program znajduje się w DNA, natomiast komórka i jej otoczenie stanowią dane $\mathrm{i}$ wynik działania programu. Jacob w następujący sposób opisał tę analogię: „Pojęcie programu stanowi zapożyczenie $\mathrm{z}$ informatyki. Materiał genetyczny przyrównuje się tu do komputerowej taśmy magnetycznej”. ${ }^{36}$ To właśnie przyjęcie takiej optyki prowadzi do uznania, że DNA „kontroluje” cały organizm.

Jednakże, jak wskazuje Coen, opisane powyżej rozróżnienie nie ma zastosowania do systemów biologicznych. Jak widzieliśmy, nawet najprostsze $\mathrm{z}$ tak zwanych sieci genów nie mogą być postrzegane jako „programy genetyczne”. Proces sam w sobie stanowi funkcję. Nie istnieje dający się wyodrębnić program. Podobne wnioski można wyciągnąć w odniesieniu do mojego obszaru badawczego, związanego z ryt-

\footnotetext{
${ }^{33}$ Por. H. Atlan and M. Koppel, „The Cellular Computer DNA: Program or Data”, Bulletin of Mathematical Biology 1990, vol. 52, s. 335-348 (doi:10.1007/BF02458575); Noble, The Music of Life....

${ }^{34}$ Por. E. Coen, The Art of Genes, Oxford University Press, Oxford, UK. 1999.

${ }^{35}$ Por. Monod and JACOB, ,Teleonomic Mechanisms in Cellular Metabolism...”.

${ }^{36}$ F. JACOB, The Possible and the Actual, Pantheon Books, New York 1982.
} 
mem serca. Nie istnieje program rytmu serca, ${ }^{37}$ a z pewnością nie istnieje genetyczny program rytmu serca, odrębny od samego tego zjawiska. Oczywiście sieci interakcji między genami, białkami, organellami, komórkami i innymi elementami możemy określić jako programy. Można również przyjąć, że przeprowadzają one swego rodzaju obliczenia $^{38}-\mathrm{w}$ pierwotnym, wprowadzonym przez von Neumanna sensie, związanym z jego teorią samopowielających się maszyn. Ale nawet jeśli zaakceptujemy ten sposób myślenia, musimy przyznać, że w toku takiego obliczenia instrukcje dotyczące wykonania danej funkcji nie są przekazywane na zewnątrz, gdyż to samo obliczenie stanowi tę funkcję.

Można argumentować, że architektura komputerów zmieniła się znacznie w porównaniu $\mathrm{z}$ latami sześćdziesiątymi. To prawda, pojęcie programu zmieniło się do tego stopnia, że rozróżnienie między danymi a instrukcjami, a nawet koncepcja programu jako pewnej logicznej całości, odrębnej od maszyny, może wydawać się już nieaktualne. Obecnie, pod względem architektury, komputery zaczynają coraz bardziej przypominać organizmy żywe.

Gen period, sam czy też jako część sieci czysto genetycznej, nie tylko nie jest czynnikiem warunkującym rytm okołodobowy, ale nawet nazywanie go genem „rytmu okołodobowego" wydaje się niepoprawne. A jeśli jednak można go tak określić, to jest on również genem rozwoju, gdyż bierze udział w rozwoju embrionu muszego. I jest on również genem zalotów! Samce mogą bowiem dzięki niemu ,śpiewać" (modulując częstotliwość uderzeń skrzydłami) samicom odpowiednich gatunków muszek owocowych (których znamy ponad trzy tysiące). Geny rozumiane jako fragmenty DNA są zatem podobne do klocków Lego, których można użyć wielokrotnie. Ogólnie rzecz biorąc, to właśnie dlatego istnieje tak niewielka liczba genów w porówna-

\footnotetext{
${ }^{37}$ Por. Noble, „Claude Bernard...”; NoBle, „Commentary on Scherrer and Jost...”.

${ }^{38}$ Por. S. Brenner, „Biological Computation”, w: G.R. Bock and J.A. Goode (eds.), The Limits of Reductionism in Biology, Novartis Foundation Symposium, no. 213, Wiley, London, UK. 1998, s. 106-116.
} 
niu z ogromną złożonością funkcji biologicznych. Rzecz jasna ludzkie zaloty są związane z innym zestawem genów! A każdy z nich znajduje zastosowanie również $\mathrm{w}$ odniesieniu do wielu innych funkcji. W mojej opinii lepiej byłoby zaprzestać używania odniesień do funkcjonalności na wyższych poziomach przy nazywaniu genów (rozumianych jako sekwencje DNA), ale zdaję sobie sprawę, że jest to walka z wiatrakami. Jedyne, co można zrobić, to wykazać śmieszność takiego nazewnictwa, dlatego tak podoba mi się historia o trubadurskim genie muszki owocowej. ${ }^{39}$

\section{Przyczynowość wyższych rzędów}

Dotychczasowe rozważania celowo sformułowane były w języku biologii molekularnej, gdyż chciałem pokazać, że krytyka determinizmu genetycznego, a także koncepcji sieci i programów genetycznych, nie opiera się wyłącznie na rozróżnieniu między przyczynowością wyższego i niższego rzędu, lecz istnieją również inne czynniki, które powinny być wzięte pod uwagę jako konsekwencja wielopoziomowych oddziaływań.

Jednakże już samo pojęcie poziomu jest tu problematyczne. Pamiętać należy, że jest to tylko metafora, choć oczywiście bardzo przydatna. W pewnym sensie komórka, narząd czy system immunologiczny są czymś więcej niż tylko sumą molekularnych części. W każdym z tych przypadków zachowanie części jest ograniczone przez funkcję całości. Ale co to dokładnie znaczy? Fizyk czy inżynier powiedzieliby, że ograniczenia nałożone na działanie poszczególnych części nie są związane $\mathrm{z}$ prawami fizyki. Zarówno molekuły biologiczne, jak i molekuły niewchodzące w obręb układów biologicznych podlegają tym samym prawom mechaniki kwantowej. Ograniczenia te związane są raczej z warunkami brzegowymi i początkowymi: „struktura staje się przyczyną". ${ }^{40}$ Ale co z kolei ogranicza same te warunki? Ostatecz-

\footnotetext{
${ }^{39}$ Por. Noble, The Music of Life..., s. 72.

${ }^{40}$ Por. R. Strohman, „Organisation Becomes Cause in the Matter”, Nature Biotechnology
} 
nie są one wynikiem miliardów lat ewolucji. $Z$ tego właśnie względu używam metafory ewolucji jako kompozytora. ${ }^{41}$ Ale i ta metafora ma swoje ograniczenia. Ewolucja może nie być ukierunkowana. ${ }^{42}$ Jest to w gruncie rzeczy seria zdarzeń - niektórzy powiedzieliby nawet: przypadków - historycznych. Informacja przekazywana w wyniku działania przyczynowości odgórnej opisuje właśnie zbiór warunków początkowych i brzegowych, bez których niemożliwe byłoby rozwiązanie równań opisujących przyczynowość na poziomie molekularnym.

W przykładzie rytmu okołodobowego wspomniane warunki to na przykład czynniki determinujące objętość cytoplazmy, w której dochodzi do zmiany koncentracji białka, tempo, w jakim przechodzi ono przez błonę jądrową, tempo, w jakim rybosomy produkują nowe białko i tak dalej. Te parametry ustalone zostały w toku ewolucji tak, że w efekcie otrzymano blisko dwudziestoczterogodzinny rytm. Rzecz jasna żadna pojedyncza molekuła biorąca udział $\mathrm{w}$ tym procesie nie „zna" ani nie reprezentuje informacji o tych warunkach, natomiast cały zbiór molekuł — tak. Sposób, w jaki taka całość oddziałuje, zmieniłby się, gdyby te warunki były inne lub w ogóle nie występowały. Na tym właśnie polega swoistość tych zjawisk molekularnych, które stanowią konsekwencję procesów życiowych. Ponadto warunki brzegowe i początkowe mają w zasadzie charakter własności ogólnych, rozpoznawalnych na poziomie, na którym - na ile da się to stwierdzić — występują.

O metaforyczności pojęcia poziomu przesądza umowny charakter pojęcia kierunku przyczynowania. ${ }^{43}$ Można przecież opisać cały ten proces od drugiej strony i mówić o przyczynowości oddolnej zamiast

2000, vol. 18, s. 575-576 (doi:10.1038/76317); Y. Neuman, „Cryptobiosis: A New Theoretical Perspective”, Progress in Biophysics and Molecular Biology 2006, vol. 92, s. 258-267 (doi: 10.1016/j.pbiomolbio.2005.11.001).

${ }^{41}$ Por. Noble, The Music of Life..., rozdz. 8.

${ }^{42}$ Przeciwko tej tezie argumentują: $\mathrm{J}_{\mathrm{ABlONK}}$ and Lamb, Evolution In Four Dimensions....

${ }^{43}$ Por. Noble, The Music of Life..., rozdz. 10. 
o przyczynowości odgórnej. Wybór należy do nas, jest on jednak o tyle istotny, że naczelna zasada redukcjonizmu każe właśnie szukać przyczyn „niższego rzędu”. Moim zdaniem to założenie redukcjonizmu wymaga uzasadnienia. Jest to jeden z przykładów tego, że nakładamy własną siatkę pojęciową na świat.

Wprawdzie pojęcie poziomu ma charakter metaforyczny, stanowi jednak podstawę koncepcji przyczynowości wielopoziomowej. Przykładem, którym często się posługuję, jest rytm rozrusznika serca. Zależy on od pewnej ogólnej własności komórek, mianowicie od ich potencjału elektrycznego, wpływającego na aktywność poszczególnych białek i kanałów jonowych, które z kolei określają potencjał. Mamy tu do czynienia $\mathrm{z}$ wielopoziomowym systemem sprzężenia zwrotnego: kanały $\rightarrow$ przepływ jonów $\rightarrow$ potencjał elektryczny $\rightarrow$ otwarcie lub zamknięcie kanałów $\rightarrow$ przepływ jonów i tak dalej. Ten cykl jest czasem nazywany cyklem Hodgkina, gdyż to właśnie Alan Hodgkin po raz pierwszy zidentyfikował go w przypadku pobudzania nerwów. ${ }^{44}$

W podobny sposób możemy opisać systemy przyczynowego sprzężenia zwrotnego wielu innych funkcji biologicznych. Moim zdaniem podstawowe zadanie biologii systemowej stanowi identyfikacja poziomu, na którym dochodzi do integracji tego typu systemów. Będzie to najwyższy poziom danego systemu, a jednocześnie najniższy poziom, na którym może operować selekcja naturalna, gdyż to właśnie funkcjonalność na wyższych poziomach wpływa na to, czy dany organizm przeżyje czy też nie. Należy odrzucić pogląd, że jednostkę selekcji stanowi gen, i uznać za nią cały organizm. ${ }^{45}$

Można jednak kwestionować również zasadność użycia pojęć, takich jak poziom czy przyczynowość. W ostatnim rozdziale mojej książki zalecam odrzucenie wszelkich metafor, gdy dzięki nim uzy-

\footnotetext{
${ }^{44}$ Por. A.L. Hodgkin and A.F. Huxley, ,A Quantitative Description of Membrane Current and Its Application to Conduction and Excitation in Nerve", Journal of Physiology 1952, vol. 117 , s. 500-544.

${ }^{45}$ Por. D. Tautz, „Redundancies, Development and the Flow of Information”, BioEssays 1992, vol. 14, s. 263-266 (doi:10.1002/bies.950140410).
} 
skaliśmy wgląd w sytuację. ${ }^{46}$ Moje wątpliwości związane są z faktem, iż użycie tych terminów może sugerować, że w przypadku cykli, w których występuje przyczynowość odgórna, przyczyny następują po sobie w czasie. Ale to nie wydaje się mieć miejsca. W rzeczywistości potencjał komórkowy wpływa na kinetykę białek w dokładnie tym samym momencie, w jakim one wpływają na potencjał komórkowy. Żaden z tych czynników nie jest podstawowy lub ważniejszy w sensie przyczynowym, czy to w czasie czy w przestrzeni. Ma to także odbicie w używanych przez nas równaniach różniczkowych. Prawa fizyki opisywane przez te równania oraz warunki początkowe i brzegowe działają $w$ tym samym momencie (to znaczy podczas każdego, jakkolwiek niewielkiego, kroku obliczeniowego), a nie jedno po drugim.

Tego rodzaju problemy konceptualne (przyczynowość nie stanowi cechy rzeczywistości, lecz jest jednym ze sposobów nadawania sensu zdarzeniom) leżą u podłoża zawiłych zagadnień dotyczących własności obserwowanych na wyższych poziomach, na przykład intencjonalności. Jak staram się wykazać w książce The Music of Life [Muzyka życia], ${ }^{47}$ wskazywanie neuronalnych czy też, co gorsza, genetycznych „przyczyn” intencjonalności stanowi przykład iluzorycznego wyjaśnienia. Wydaje się, że to $\mathrm{z}$ tego względu pojęcie przyczynowości odgórnej może odegrać istotną rolę w filozofii działania (na gruncie której bada się takie kwestie jak intencjonalność czy problem wolnej woli).

Poza tym przyczynowość, w jakiejś szczególnej formie, nie jest koniecznym składnikiem każdej uznanej teorii naukowej. Ogólna teoria względności, na przykład, zmienia naturę przyczynowości poprzez zastąpienie ruchu $\mathrm{w}$ przestrzeni liniami geodezyjnymi w strukturze czasoprzestrzeni. Ten przykład pokazuje co najmniej, że proces wymagający w pewnym podejściu teoretycznym jednej formy przyczynowości (siły przyciągania działającej między ciałami na odległość) może być uznany za zbędny z punktu widzenia innego podejścia teo-

\footnotetext{
${ }^{46}$ Por. Noble, The Music of Life..., rozdz. 10.

${ }^{47}$ Por. Noble, The Music of Life..., rozdz. 9.
} 
retycznego. Ponadto istnieje wiele rodzajów przyczynowości, począwszy od przyczyn bezpośrednich (jedna kula bilardowa uderzająca w drugą), a skończywszy na przyczynach pierwotnych — na przykład tych poszukiwanych przez biologów ewolucyjnych w celu wyjaśnienia wartości przystosowawczej funkcji i cech biologicznych. Przyczynowość genetyczna to bardzo złożony problem nie tylko dlatego, że, jak starałem się wykazać w tym artykule, pojęcie genu jest samo w sobie problematyczne, ale też z tego względu, że gen zwykle nie stanowi przyczyny bezpośredniej. Od genów, tak jak je zdefiniowano obecnie w biologii molekularnej, jeszcze daleko do ich skutków o charakterze fenotypowym. Po drodze trzeba przejść przez wiele poziomów organizacji biologicznej, za każdym razem biorąc pod uwagę nie tylko właściwe danemu poziomowi czynniki, lecz także wpływ otoczenia. Nie wiemy, jakie teorie wyjaśniające fenomen życia powstaną w przyszłości, ale możemy mieć niemal całkowitą pewność, że nasze ujęcia życia nie są jedynymi możliwymi. Być może wypracowanie nowych teorii wymaga fundamentalnej zmiany sposobu myślenia, a mam nadzieję, że ten artykuł do takiej zmiany się przyczyni.

\section{Zrozumienie przyczynowości genetycznej: rozwiązanie problemu genetycznego efektu różnicowego}

Wspomniałem o tym problemie wcześniej i obiecałem go rozwiązać. Problem ów powstaje ze względu na inherentną słabość wyjaśniania ukierunkowanego „do przodu” (wyjaśniania redukcjonistycznego). Zważywszy na zdolność organizmów do naprawy błędów genetycznych poprzez tak zwane buforowanie genetyczne (niegdyś stosowano nazwy „mechanizmy redundancji” lub „mechanizmy pomocnicze”), uruchamiane $\mathrm{w}$ momencie zagrożenia utratą funkcjonalności, następstwa zmian na najniższym poziomie łańcucha przyczynowego (to znaczy na poziomie genów) mogą pozostawać ukryte. Rozwiązanie naszego problemu polega na tym, by nie opierać się wyłącznie na wyjaśnianiu ukierunkowanym do przodu. Wyjaśnianie ukierunkowane $\mathrm{w}$ drugą stronę jest czasem nazywane inżynierią odwrotną. Powinni- 
śmy zaczynać proces wyjaśniania od wyższego, funkcjonalnego poziomu, używając modelu obejmującego wyjaśnienia ukierunkowane do przodu, ale, co bardzo istotne, uwzględniającego również wgląd w funkcjonalność na wyższych poziomach. Na przykład, jeśli potrafilibyśmy ująć $\mathrm{w}$ danym modelu relacje między wszystkimi białkami związanymi z rytmem serca, wówczas moglibyśmy wykorzystać ten model, by jakościowo i ilościowo ocenić wkład każdego produktu genu do danej funkcji. W tym przejawia się siła inżynierii odwrotnej. Nie mamy tu już do czynienia wyłącznie $\mathrm{z}$ obserwacją różnic. Jeśli model jest odpowiedni, to potrafimy określić wszystkie funkcje danego genu w modelowanym procesie. Możemy nawet ilościowo określić wkład danego produktu genu, którego efekty są całkowicie lub częściowo buforowane, gdy ów gen zostanie poddany manipulacji. ${ }^{48}$ $\mathrm{Z}$ tego właśnie względu modelowanie funkcji biologicznych na wyższych poziomach jest istotną częścią procesu rozpoznawania funkcji genów: „Ostatecznie sztuczne genomy in silico i naturalne genomy in vivo staną się wzajemne przekładalne, co zapewni możliwość zarówno wyjaśniania ukierunkowanego do przodu, jak i stosowania inżynierii odwrotnej w odniesieniu do genomów naturalnych". ${ }^{49}$

\section{Wnioski}

Pierwotnie pojęcie genu ściśle wiązało się z przyczynami poszczególnych cech fenotypowych, zatem określanie związków przyczynowych między genami a fenotypem, jako problem oparty na błędnym kole, nie miało zbyt wiele sensu. Problem przyczynowości jest obecnie poważny ze względu na to, że geny definiuje się dużo węziej, jako konkretne sekwencje DNA. Kłopot w tym, że tych sekwencji nie da się zinterpretować poza kontekstem komórki, w której następuje ich odczytanie i w konsekwencji wytworzenie danej funkcji. To z kolei oznacza, że komórka stanowi również istotną część procesu dziedzi-

\footnotetext{
${ }^{48}$ Por. Noble, The Music of Life..., s. 108.

${ }^{49}$ E. Werner, „Genome Semantics. In silico Multicellular Systems and the Central Dogma”, FEBS Letters 2005, vol. 579, s. 1779-1782 (doi:10.1016/j.febslet.2005.02.011).
} 
czenia, a zatem była, przynajmniej domyślnie, częścią pierwotnej definicji genu. W zależności od sposobu wyliczenia względnego wkładu komórki i genu w tym kontekście, może się nawet okazać, że to wkład komórki jest większy. Informacja genetyczna jest czymś więcej niż tylko cyfrową informacją zawartą w genomie. Obejmuje również informację analogową znajdującą się w zapłodnionej komórce jajowej. Jeżeli kiedykolwiek zechcemy wysłać w kosmos kapsułę zawierającą informację niezbędną do odtworzenia ziemskiego życia na jakiejś odległej planecie, to będziemy musieli przesłać oba te rodzaje informacji. W czasach, gdy potrafimy już sekwencjonować całe genomy, najtrudniejszym wyzwaniem wydaje się zakodowanie informacji dotyczących komórki. Sydney Brenner powiedział: „Jestem przekonany, że podstawową jednostką, odpowiednim poziomem abstrakcji, nie jest genom, lecz komórka". ${ }^{50}$ Ta fundamentalna prawda musi jeszcze poczekać na pełną akceptację biologów, co pomoże w zrozumieniu złożoności wzajemnych oddziaływań między genami a ich środowiskiem. W szczególności, należy docenić użyteczność inżynierii odwrotnej, która dzięki zastosowaniu matematycznego modelowania funkcji biologicznych umożliwia rozpoznanie funkcji danego genu. Wielopoziomowa biologia systemowa wymaga bardziej złożonego języka do opisu zależności między genomami a organizmami.

Praca badawcza w laboratorium autora jest wspierana przez sieć EU FP6 BioSim, projekt EU FP7 PreDiCT, BBSRC i EPSRC. Chciałbym podziękować Jonathanowi Bardowi, Johnowi Mulveyowi, Jamesowi Schwaberowi i Ericowi Wernerowi za konstruktywne dyskusje oraz recenzentom za uwagi krytyczne.

Denis Noble

${ }^{50}$ Odczyt na Columbia University w 2003 roku. 